\title{
El telèfon mòbil: dimensió i recurs educatiu. Treballar amb imatges en el context de les arts visuals
}

\author{
David Mascarell Palau *
}

Resum

Aquest article s'emmarca en els resultats de la tesi doctoral Les TIC en la formació universitària de mestres. El telèfon mòbil en la Didàctica de l'Expressió Plàstica a la Facultat de Magisteri de la Universitat de València, i ofereix una visió polièdrica del telèfon mòbil. Dimensió, evolució, funció social i històrica, fins arribar a qüestionar les oportunitats que aporta aquest dispositiu en una vessant de caràcter educatiu i artístic, a través de l'aprenentatge en mobilitat. El nostre interès radica, des de la perspectiva de les arts visuals, en el treball mitjançant les imatges, oferint propostes alternatives de treball. S'exposa la teoria relativa al Mobile Learning, mostrant els beneficis que pot suposar l'aprenentatge mòbil i ubic als nostres dies. $S^{\prime}$ hi avaluen les oportunitats pedagògiques que cal fomentar a les aules del segle XXI per ser conseqüents amb la realitat social i tecnològica que ens envolta.

\section{Paraules clau}

Telèfon mòbil, educació, aprenentatge en mobilitat, imatges, arts visuals, magisteri.

Recepció original: 21 de novembre de 2019

Acceptació: 06 de març de 2020

Publicació: 30 de juny de 2020

\section{El telèfon mòbil, dimensió i funció}

Les formes de comunicació han canviat degut al desenvolupament tecnològic. S'han modificat les maneres com accedim a la informació i al coneixement. Són dos els factors que han resultat clau en aquest procés: per una banda el mòbil, com a dispositiu tecnològic majoritàriament emprat en qualsevol sector social, de fet, resulta significatiu que la telefonia mòbil és la que més ràpidament s'ha desenvolupat en la història. I d'altra banda Internet, que ha fet possible la connectivitat i que a hores d'ara és un recurs generalitzat. La simbiosi d'aquests dos factors ha donat com a resultat la clau de la nova era Internet mòbil.

En el moment actual els terminals mòbils ja no s'ajusten a l'exclusiva catalogació semàntica de «telèfons». La tecnologia mòbil ha evolucionat a gran velocitat, els mòbils han ampliat prestacions i avançat en la funcionalitat de les seues característiques, fins arribar als populars smartphones. La venda d'aquests aparells ha experimentant en la darrera dècada un creixement exponencial; el preu assequible de comercialització, la reducció en les mides, així com l'existència de nombroses i variades aplicacions (apps) els ha catapultat a ser els representants tecnològics de major popularitat. La denominació amb que se'ls ha batejat ens acosta a la nova concepció a què al.ludim, allunyada de la representació tradicional de telèfon com a mitjà per una comunicació oral a distància, i escrita a partir de l'entrada en escena dels SMS (Short Message Service), servei de missatges simples, inventat l'any 1985 per Matti Makkonen. L'epítet smart, intel-ligent, atorga als terminals una magnitud extraordinària. La idea original era aconseguir un aparell que fusionés

(*) Professor associat doctor, àrea de Didàctica de l'Expressió Plàstica. Departament de l'Expressió Musical, Plàstica i Corporal de la Universitat de València. Adreça electrònica: david.mascarell.palau@uv.es 
les funcions tradicionals del telèfon mòbil amb les de les PDA (personal digital assistant) o ordinadors/agendes de butxaca, combinant en un sol dispositiu la funcionalitat dels altres dos. La història té el punt d'inflexió en el llançament al mercat de l'iPhone i de iOS per part de la companyia Apple en 2007. Aquest sistema operatiu donaria lloc uns mesos més tard al competidor directe, Android, OS, sistema operatiu de la companyia Google.

L'extensió i generalització del telèfon mòbil en les societats actuals forma part de la quotidianitat, de fet, el mòbil forma ja part de la nostra identitat. Resulta eloqüent observar l'evolució de vendes que en els darrers anys han experimentat els telèfons mòbils, i com Android ostenta major popularitat entre els principals sistemes. En l'actualitat es venen més smartphones que ordinadors personals. I no solament això sinó que s'utilitzen més. Estem encara en plena «revolució mòbil». Des d'àmbits ben diversos es vaticinava que abans de 2020 els telèfons mòbils serien el principals dispositius d'accés a Internet. Encara no hem tancat la segona dècada del segle XXI i es confirma que els smartphones superen als PC com a principals dispositius per a l'accés a Internet. Els usuaris s'han apropiat de la tecnologia que el sustenta, adaptant-la a les pròpies necessitats, és el que alguns autors (Ramírez, 2009) anomenen apropiació tecnològica que es concreta en el següents nivells:

- Apropiació de l'objecte. Tecnologia superficial.

- Apropiació de la funcionalitat. Familiaritzar-se amb la tecnologia.

- Apropiació de les noves formes d'aprenentatge. Emprar la tecnologia com eina d'aprenentatge per tal de desenvolupar projectes educatius.

Una de les característiques més rellevants d'aquest aparell són les múltiples possibilitats que ofereix, no solament com a instrument de comunicació, sinó també d'expressió social, oci i informació, sempre sota una elevada aportació d'autonomia per a l'usuari. Com a "instrument a la carta" que cadascú utilitza i configura en funció dels seus interessos, objectius i necessitats puntuals, permet estar localitzat, parlar, jugar i recrear-se en el moment que es decidisca, únicament limitats per òbvies qüestions de caire material com són la càrrega energètica o bateria, el component tècnic o cobertura i la part econòmica o saldo/cost del contracte. Dins la seua dimensió instrumental cal diferenciar entre la funció comunicativa bàsica i la funció lúdic-expressiva. La primera fa referència al caràcter bidireccional i interactiu de comunicació mitjançant la veu, missatges, tons, sentiments o decisions. La segona es relaciona amb usos recreatius vinculats a l'oci, el joc i expressions creatives (fotos, vídeos, ....).

Per centrar l'interès del tema del present text aprofundim en la vessant referida a la funció lúdica i expressiva. Cal diferenciar dues opcions depenent del grau i del mode d'interacció de l'usuari. Així, observem d'una banda l'ús recreatiu del mòbil: com a substitut de la consola de joc o videojoc, dels reproductors de música, de la ràdio o la televisió. I d'altra banda un ús actiu, inventiu, creatiu i expressiu, de producció, relacionat amb la manipulació de dispositius integrats en el terminal com ara càmera fotogràfica i vídeo càmera digitals, que requereixen certa planificació/decisió per l'usuari encaminada a obtenir com a resultat un producte. Evidentment, aquests usos estan limitats per les particulars prestacions dels diferents tipus de mòbils. L'accés a Internet ha aconseguit la immediatesa, potenciant i ampliant les possibilitats, tant dels usos recreatius (descàrrega de jocs, jocs en línia, música, xats, apps), com dels usos creatius: descàrrega des de pàgines web de materials i càrrega d'imatges fotogràfiques i vídeos que queden a disposició 
dels internautes amb més o menys disponibilitat depenent de les opcions de privacitat que oferisca l'espai seleccionat per al seu allotjament virtual. Els terminals mòbils aporten una important dimensió simbòlica, que té a veure amb l'aparença, l'estètica externa del terminal o les prestacions, la marca i el preu. Simbòlicament s'associa a uns significats, codis i valors que contribueixen a configurar en el propietari una imatge concreta que serà valorada socialment i que el situarà en un o altre estrat de la subcultura a què pertany.

\section{Breu historia del telèfon mòbil}

Fem una aproximació a l'evolució dels telèfons mòbils per a una comprensió de la dimensió adquirida i de quina manera es produeix l'expandiment en les funcionalitats. Els inicis de la telefonia a distancia s'ubiquen en la Segona Guerra Mundial. La companyia Motorola va crear un equip nomenat Handie Talkie H12-16, un aparell que transmetia informació per ones de radio. Entre els anys 1970 i 1973 neix la telefonia mòbil als Estats Units, essent el 1983 quan va sortir al mercat. Martin Cooper està considerat el pare dels telèfons mòbils. Es tractava d'un aparell amb una durada de conversa d'una hora i la possibilitat de romandre vuit hores en stand-by. El 1979, a Tokio, s'inicia la venda comercial per la companyia NTT. A Europa, la marca Ericsson introduí l'any 1981 un sistema telefònic mòbil avançat (AMPS: Advanced Mobile Phone System). Aquest va ser el primer sistema de telefonia mòbil del món tal com l'entenem a dia d'avui. En 1986 va sorgir una segona variant la NMT-900 que podia emprar més canals. La segona generació de telèfons mòbils (2G) va arribar en la dècada de 1990. Va suposar el canvi de protocols de telefonia mòbil analògica a digital.

Abans d'arribar a la tercera generació emplacem un punt de trànsit en la pseudotecnologia $2.5 \mathrm{G}$, coneguda com «generació de transició» perquè mantenint-se com a telèfons mòbils $2 \mathrm{G}$ incorporen algunes millores de la generació $3 \mathrm{G}$. El sistema MMS (Sistema de Missatgeria Multimèdia) enviat mitjançant GPRS va permetre la inserció d'imatges i so, text i vídeos de menys de 15 segons de durada. La tercera generació (3G) augmentà la capacitat de transmissió de dades amb connexió a Internet des dels terminals mòbils. Ja la quarta generació (4G) disposa de tècniques d'avançat rendiment i un ample de banda que multiplica la rapidesa. Un tret referit a l'arquitectura dels terminals mòbils resulta significatiu en el tema del nostre interès per a la representació de les imatges: la pantalla. Aquestes superfícies han experimentat importants canvis referits a dimensions, resolució i accés (interacció per teclat extern a la pantalla o intern/tàctil).

L'augment de prestacions i aplicacions dels terminals ha requerit millorar la qualitat de la informació visual. A hores d'ara la pantalla, la potència dels terminals, i la càmera fotogràfica integrada, són els tres pilars d'un telèfon mòbil. L'any 1997 l'empresari i innovador tecnològic Philippe Kahn, aconseguí el seu propòsit connectant la càmera fotogràfica digital i un ordinador portàtil a un terminal mòbil mitjançant cables del sistema de ràdio del seu automòbil. Arran d'aquesta acció va treballar per a Motorola desenvolupant el primer telèfon mòbil amb càmera digital pròpia. Tot i això, la primera càmera de mòbil coneguda comercialment és la del Samsung SCH-V200, un terminal Ilançat des de Corea del Sud el juny de 2000.

En 2002 va arribar als Estats Units el Sanyo SCP-5300, un telèfon amb forma de conxa i una càmera integrada de 0,3 MP. Amb aquest aparell es va iniciar la cursa en l'ampliació 
i millora no solament de les característiques d'aquestes càmeres sinó també dels múltiples recursos de manipulació i modificació de la imatge que ofereixen els smartphones d'última generació. El telèfon mòbil ha passat a ser l'aparell principal per a la captura d'imatges per sobre de les càmeres fotogràfiques pròpiament dites.

\section{El telèfon mòbil com a element socialitzador}

L'any 2012 el 85,3\% dels internautes de 16 a 24 anys edat es connectaven diàriament a Internet. I quasi tres de cada quatre joves de 14 a 19 anys ho feien més de dues hores al dia. Pel que fa a l'Estat Espanyol, en 2015, el 88,3\% dels usuaris utilitzen el mòbil com a medi de connexió a Internet. En 2017 es va superar la barrera dels 3.000 milions d'internautes a nivell mundial. L'interval d'edat on més s'ha experimentat un augment en l'ús d'Internet és entre els 55 i 64 anys. Amb la telefonia mòbil s'ha aconseguit la important fita d'acurtar la cèlebre bretxa. Els objectius principals en les connexions són: el 81,5\% per consultar el correu electrònic, el 78,6\% per accedir a notícies d'actualitat, el 69,6\% per recerca d'informació, i el 67,5\% per al consum de pel-lícules, vídeos i música. Entre els joves s'experimenta darrerament un lleuger creixement en l'interès per serveis diferents a la comunicació i l'oci, com són el comerç electrònic o les plataformes d'educació on line. La connectivitat ha deixat de ser un fi en sí mateix per a convertir-se en un medi per a altres coses. És el segment de població que es troba en un moment crucial per a la formació de la pròpia identitat qui fa major ús d'aquesta tecnologia. És entre els i les joves on l'actualitat digital ha calat de tal manera que de la interrelació generada han sortit múltiples etiquetes o denominacions: generació Net, generació Multipantalla, generació Interactiva, generació @, generació Xarxa, generació Multitasques, o la més difosa generació Mòbil. Bona part de la investigació social (Levinson, 2004; Cabrera, 2011) vinculen l'ampli desenvolupament del telèfon mòbil en els conceptes sociològics de grup i de relacions primàries, en la necessitat d'identitat i de comunicació. Aquesta necessitat construeix l'entramat social de valors, normes i comportaments de l'individu i del grup. La hiperconnexió virtual en què es viu modifica els esquemes espai temporals tradicionals de les relacions socials. Predomina una situació d'ubiqüitat versus els contextos físics i temporals particulars. Estem assistint a un canvi total d'escenari. Els nous elements tecnològics han envaiit tant els contextos públics com els privats, donant lloc a noves possibilitats en les relacions interpersonals.

Els mitjans de comunicació generen diferents funcions que tracten de satisfer en els joves les necessitats psicològiques de caire social, com ara:

- Funció d'escapament. L'usuari ha d'identificar-se amb un personatge de ficció, jocs virtuals o xats.

- Funció de compensació emocional. Ús del dispositiu per establir noves relacions socials.

- Funció de companyia. Acompanya les activitats diàries o quotidianes.

- Funció informativa. Ofereix informació a l'instant.

- Funció de reafirmació individual. Increment de l'autoestima.

La pròpia evolució del telèfon mòbil ha generat una cultura que gira al seu voltant, produint sinèrgiques interrelacions socials que han transcendit i modificat les estructures freqüents d'hàbit comunicatiu social en les relacions interpersonals. Aquesta situació ha 
estat reforçada pel progressiu increment del consum de la tecnologia portable, impulsat per les millores implantades als terminals i per l'expansió, acceptació i popularitat de les xarxes socials. Hem creat l'aparell tecnològic per necessitat, i ara ens trobem necessitats de l'aparell tecnològic.

En un món definit per la velocitat, la mobilitat i l'obsolescència, la tecnologia del dispositiu mòbil proporciona una gestió de les relacions socials i, per tant dels grups de pertinença, mediada per la connectivitat en xarxa i instrumentalitzada per les idòniament anomenades xarxes socials, on els usuaris poden interactuar, actualitzar i fer recerca instantània de la informació que els permetrà estar, participar o fins i tot «ser part de» en temps real (García i Monferrer, 2009).

\section{El telèfon mòbil i les xarxes socials}

Segons Abad y Palacios (2008, p. 195): «Para los educadores artísticos las ocasiones de aprendizaje artístico no aparecen únicamente en las aulas y museos sino en cualquier situación social». Connectant amb el pensament de Prensky (2011, p. 11) «un nuevo mundo virtual (por ejemplo, en línea) ha surgido de la nada y se ha convertido en el foco de atención de muchos de nuestros chicos». El cos del nou entramat de relacions socials sorgides arran del desplegament tecnològic està sustentat per un esquelet que vertebra les comunicacions en línia: les xarxes socials. Boyd i Ellison (2007) les defineixen com els serveis en xarxa on crear un perfil personal amb el qual l'usuari s'identifica davant la resta de contactes, i on tots ells es connecten i naveguen. És en el moment actual quan estan començant a proliferar estudis al voltant de les xarxes socials i les implicacions en diferents àmbits (social, educatiu, familiar, etc.). Fins ara poques investigacions de caràcter científic han parat atenció a l'ús que se'n fa i encara resulta més dificultós trobar literatura al respecte de les possibles aplicacions pedagògiques en Educació Artística.

Fa dues dècades Manuel Castells va introduir el terme societat xarxa en al.lusió a un nou ordre econòmic i social instaurat per les xarxes de comunicació. Les xarxes socials s'han convertit en un fenomen de masses que afecta a la globalitat de la societat i que entre els joves troba una forma d'expressió natural «en virtualitat». Es tracta del punt de trobada en «el núvol» del grup d'iguals amb coincidents interessos. L'informe de la Fundación Telefónica (2016) ha constatat que cada dues vegades que accedim a Internet, una és per fer-ho a una xarxa social. Aquests allotjaments virtuals poden representar avantatges importants en els ambients educatius ja que faciliten als estudiants (i també als docents) el diàleg, la col-laboració, el compartir recursos, continguts i materials. Es tracta de procediments que els sistemes de gestió educativa tradicionals han tractat d'incentivar les darreres dècades en els processos d'ensenyament. Les principals variacions al-ludeixen a com s'han modificat les relacions de poder en l'ensenyament, com s'han transformat els rols i com han sorgit nous i infinits espais on resideix la informació (blocs, wikis, vídeo en línia, podcasts, recursos educatius oberts).

Les connexions en xarxa permeten els estudiants relacionar-se i interactuar entre ells i amb el professorat. Davant d'aquesta realitat, aproximem i introduïm les xarxes socials en el terreny educatiu des de dues vessants, la formativa i l'educativa. Ens referim a l'ús instrumental del recurs, les xarxes socials com un medi més per contribuir al procés formatiu dels estudiants. S'obri un ventall infinit de possibilitats, principalment pel que es 
refereix a ubicació espai-temporal, que desenvoluparem en apartats posteriors. En el segon cas estaríem parlant d'oferir una guia per a un ús crític, conscient i constructiu de les xarxes.

Les xarxes socials aplicades a l'àrea d'Educació Artística es presenten com un recurs insospitat i amb un potencial poc explorat. Hem de tindre present que la comunicació en gran part de les xarxes socials de major popularitat, té un altíssim component visual. Els ingredients configuren una sucosa recepta: imatge, fotografia, vídeo, intercanviar, compartir, comunicar, informació, experiències, acció, col·lectivitat, i tot això sense limitacions d'espai ni de temps. S'aprecien com elements a priori engrescadors per als usuaris, principalment el públic més jove. A Espanya el 98,9\% de la població juvenil afirma participar en xarxes socials com ara Facebook, Twitter, WhatsApp o Instagram. Essent el telèfon mòbil el principal medi d'accés, per sobre de l'ordinador, fins i tot el portàtil. Les justificacions exhibides ens ajuden a recolzar la idea que en la recerca d'estratègies que afavorisquen una actualització en la Didàctica de l'Educació Artística, de manera coherent a la realitat social, que prepare els alumnes per viure amb consciència plena en aquesta era visual i a assolir les competències necessàries per afrontar el futur, trobem la possibilitat de partir dels aprenentatges significatius, d'ubicar punts d'ancoratge per a la motivació intrínseca, de fomentar la connectivitat, el treball collaboratiu, tot aprofitant el codi diari dels procediments comunicatius dels joves del segle XXI.

\section{El telèfon mòbil com a recurs educatiu}

L'expansió de les tecnologies de la informació està plantejant nous reptes al món educatiu. El fet que la comunicació es puga realitzar en unes coordenades espai-temporals diferents a les que no fa massa es consideraven habituals, genera perspectives que eren impensables fa només dues dècades. L'ensenyament propi de la industrialització s'havia caracteritzat per seguir les lleis de les tres unitats: de temps, de lloc i d'acció. Però ara trobem que aquesta llei s'esvaeix sota les possibilitats de les telecomunicacions portables que fan possible, no solament comunicar-nos en qualsevol lloc en qualsevol moment, sinó accedir a la informació en diferents circumstàncies. Aleshores cal qüestionar-nos si hem de seguir limitant els processos d'ensenyament-aprenentatge a les parets de l'aula o si convé que la classe no siga l'entorn exclusiu per a la formació. Si es pot aprendre, entenem que més i millor, en altres ambients, caldrà contemplar-ho. La diversificació enriquirà els processos i augmentarà les possibilitats. Tot i això cal prestar atenció als perills d'aquesta implantació ja que els canvis educatius recolzats en les TIC poden no tindre el nivell desitjat d'implantació i ens podem trobar amb el mateix model d'aprenentatge però amb un suport diferent al tradicional.

Amb les noves formes de comunicació s'han ocasionat noves formes de treball i per tant nous termes que les designen. Així és com arribem a l'aprenentatge en mobilitat, mLearning, possible gràcies a les tecnologies portables. Ramírez $(2009$, p. 61$)$ ens aporta una definició genèrica de dispositiu mòbil, adaptable als àmbits on transcorren els processos d'ensenyament i aprenentatge:

Un dispositivo móvil es un procesador con memoria que tiene muchas formas de entrada (teclado, pantalla, botones, etc.), también formas de salida (texto, gráficas, pantalla, vibración, audio, cable). Algunos dispositivos móviles ligados al aprendizaje son las laptops, teléfonos celulares, teléfonos inteligentes, asistentes personales digitales (Personal Digital Assistant, PDA, por sus siglas en inglés), reproductores de audio portátil, iPods, relojes con conexión, plataforma de juegos, etc.; conectada a Internet, o no necesariamente conectada (cuando ya se han archivado los materiales). 


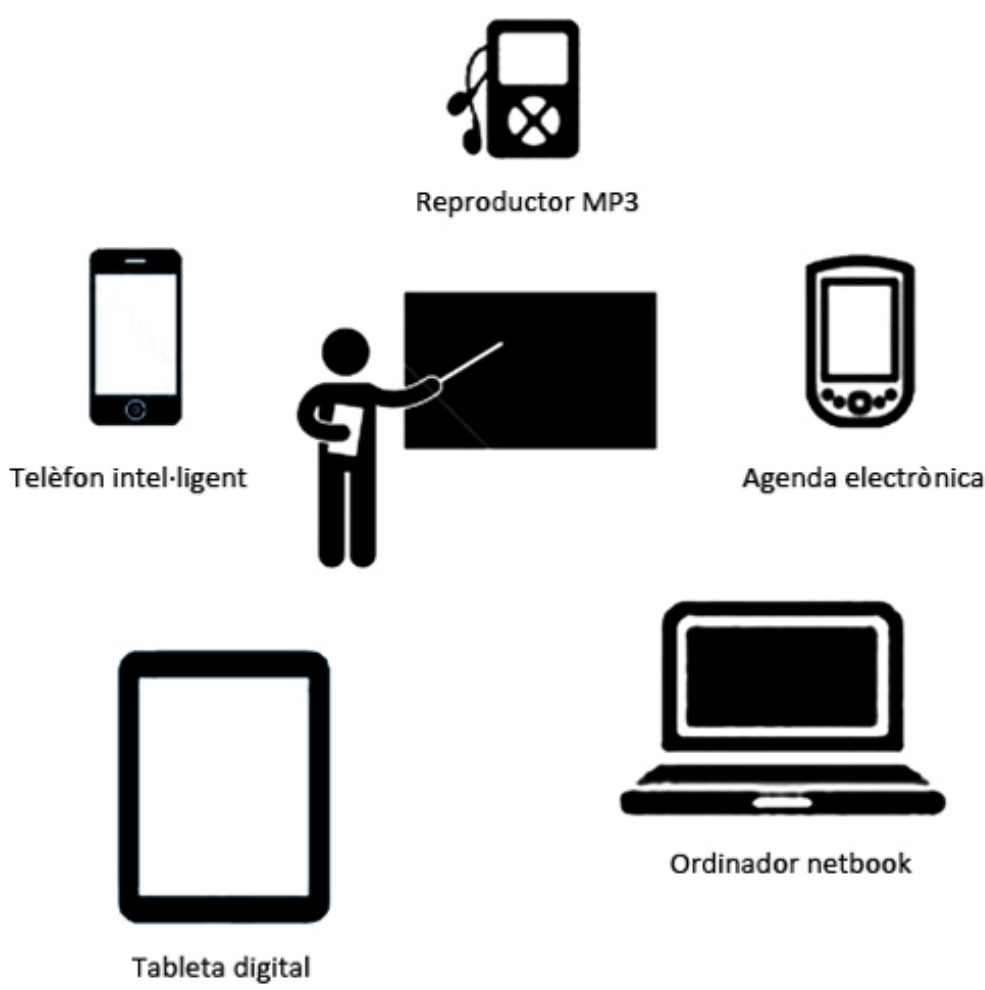

\begin{tabular}{|c|c|}
\hline Reproductor MP3 & $\begin{array}{l}\text { Dispositiu que emmagatzema, organitza i reprodueix arxius d'àudio digital o } \\
\text { podcast. Permet la gravació de veu o sons. }\end{array}$ \\
\hline $\begin{array}{l}\text { Agenda electrònica o Per- } \\
\text { sonal Digital Assistant } \\
\text { (PDA) }\end{array}$ & $\begin{array}{l}\text { És un dispositiu o hardware equivalent a un ordinador a escala reduïda, pen- } \\
\text { sat originàriament amb ús d'agenda o organitzador personal. Se'l designa } \\
\text { també amb el mot anglès handheld, ja que la característica principal que el } \\
\text { defineix i diferencia dels ordinadors portàtils és que pot utilitzar amb una } \\
\text { sola mà. }\end{array}$ \\
\hline Ordinador netbook & $\begin{array}{l}\text { És un tipus d'ordinador portàtil de dimensions reduïdes, característica que } \\
\text { en permet la mobilitat. La mida de la pantalla pot oscil·lar entre les } 7 \text { i les } 14 \\
\text { polsades. Incorpora teclat físic. }\end{array}$ \\
\hline Tableta digital & $\begin{array}{l}\text { Dispositiu amb pantalla tàctil i teclat virtual que funciona com una mena } \\
\text { d'ordinador a escala reduïda. Orientat principalment a aspectes multimèdia, } \\
\text { aplicacions, accés a continguts i navegació per xarxa. }\end{array}$ \\
\hline Smartphone & $\begin{array}{l}\text { Telèfon intel-ligent que ofereix prestacions similars a les d'un ordinador. El } \\
\text { funcionament depén del sistema operatiu que incorpora. Pensat originària- } \\
\text { ment per a la comunicació personal. Pantalla tàctil. Teclat virtual. Càmera fo- } \\
\text { togràfica. }\end{array}$ \\
\hline
\end{tabular}

\section{Cap a una educació mòbil. Evolució històrica}

El recorregut històric de les tecnologies en el terreny educatiu ha derivat els darrers anys en una tendència cap als aprenentatges asincrònics. Amb la intenció de contextualitzar com ha progressat iniciarem l'anàlisi en el moment en què emergeix el concepte d'educació a distància a la dècada de 1950.

- Dècades 1950-1960, s'inicia l'ús de medis audiovisuals: Plantegen la possibilitat de formar-se sense necessitat d'assistència completament presencial. 
- Dècada 1970, teleeducació: Expansió medis de comunicació de masses (ràdio, televisió).

- Dècada 1980, expansió dels ordinadors personals: Amb els primers ordinadors personals s'inicia una revolució tecnològica (la tecnologia informàtica envaeix el món educatiu).

- Dècada 1990: aparició del CD-Rom interactiu que permet la formació fora de l'espai habitual de docència, tot i que manté la metodologia de les sessions presencials.

- Dècada 2000, expansió i penetració d'Internet, ensenyament basat en web (webbased teaching): Permet apostar per l'aprenentatge en línia com a complement a la formació presencial.

- Fins l'actualitat, evolució plataformes virtuals, tecnologia mòbil i connexions: El Web 2.0 juntament amb la integració i popularització de tecnologies per a la comunicació amb connexió a la xarxa i totalment interactives condueixen cap a una nova concepció educativa ubiqua.

La metodologia Mobile Learning s'inicia amb tímides experiències a les aules a mitjans de la dècada dels anys 90 . És a començaments del segle XXI quan germina amb força el seu ús i aplicació. Però segons els autors, el Mobile Learning com a temàtica pròpia d'investigació en tecnologies de l'educació, comença aproximadament en la primera dècada del present segle. Els experts en innovació tecnològica educativa i pedagogia preveuen que el termini d'integració en les aules espanyoles de l'aprenentatge mòbil com a nou mètode pedagògic serà efectiu entre 2018 i 2020 (Pérez i Pi, 2014). La taula 2 exemplifica una proposta de progressió temporal en la integració de nous mètodes pedagògics en les aules espanyoles, alguns dels quals estan directament relacionats amb el desenvolupament tecnològic.

\section{Taula 2. Les aules del segle XXI. Previsió d'integració de noves metodologies pe- dagògiques fins 2020}

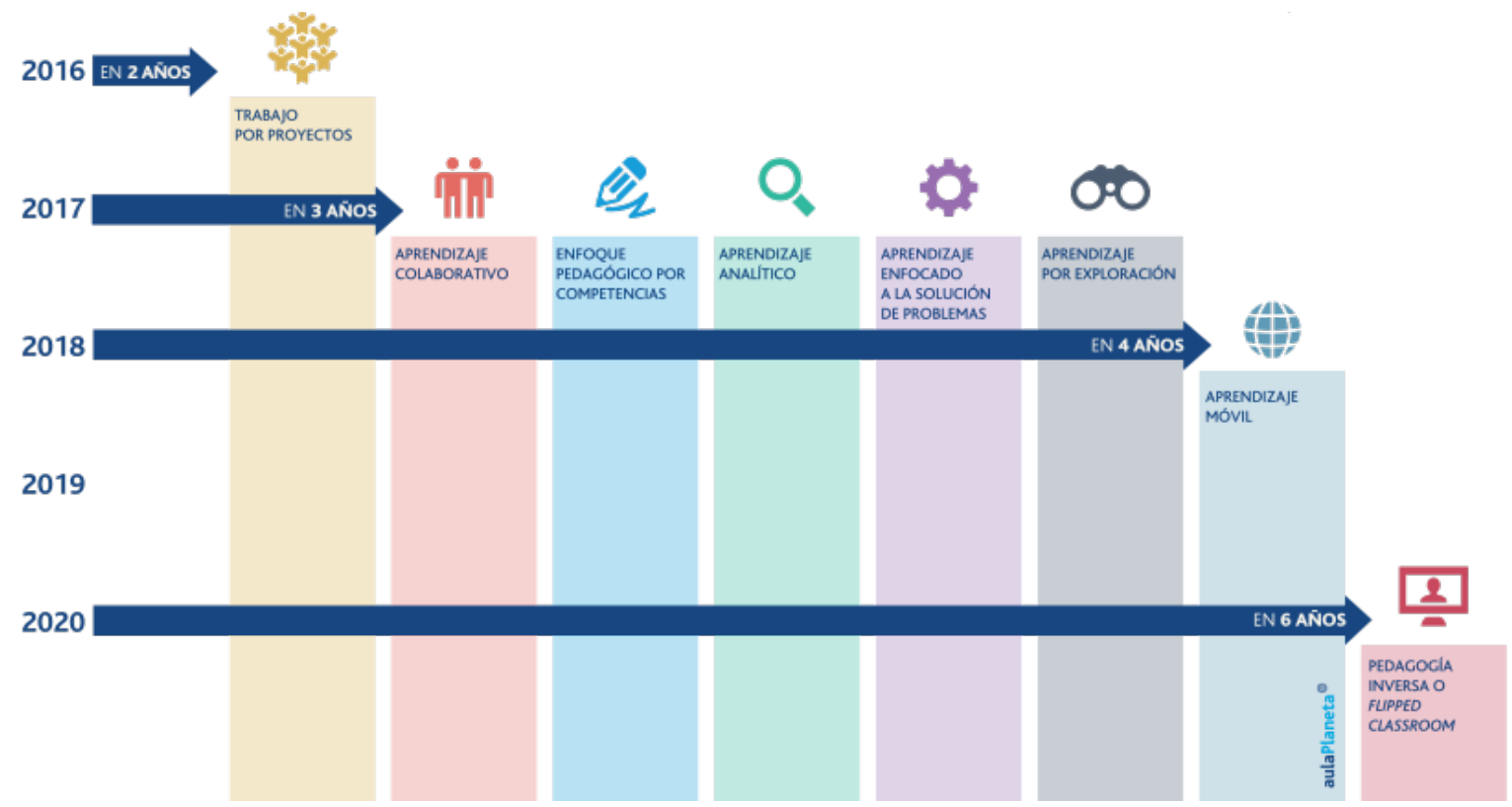

Font: Aula Planeta. 


\section{MLearning, bases conceptuals}

L'itinerari històric desemboca en el concepte d'aprenentatge en mobilitat: mLearning. Al voltant d'aquesta denominació fluctuen terminologies pròximes, però amb matisos al.lusius a formes i continguts, que transiten des de l'eLearning fins l'uLearning. No es tracta de conceptes excloents sinó que conviuen i es solapen en el temps. Per a una comprensió apropiada a tot el que implica l'aprenentatge mòbil, assentarem les bases conceptuals que delimiten cada expressió, a saber: eLearning, mLearning, uLearning. Completarem l'enquadrament conceptual amb una aproximació a sLearning, bLearning i dLearning.

eLearning, electronic-learning o aprenentatge electrònic. Queda definit per la conjugació de tres elements: Tecnologia, comunicació i aprenentatge. Tenim aleshores una educació a distància virtual gràcies als medis electrònics. Entre ells trobarem un ample ventall en funció de les característiques de l'organització didàctica i els objectius, des de les connexions a la xarxa Internet, intranets, plataformes virtuals, dispositius portables, CD-ROM, presentacions multimèdia,... que facilitaran i dinamitzaran la comunicació entre usuaris, l'accés a la informació i, en última instància, a un coneixement personalitzat i flexible. Es configura doncs com una atractiva opció per als ensenyaments artístics ja que permet introduir els continguts audiovisuals amb facilitat. Evidentment suposa un canvi en les relacions i rols dels actors del procés ensenyament-aprenentatge, esborrant jerarquies i establint noves formes de treball.

Són molts els autors que consideren l'aprenentatge en mobilitat com l'evolució natural del elearning, situació lògica a causa dels avanços en el camp tecnològic. Seria aquesta una de les quatre tendències actuals. Les altres tres definirien mLearning en funció del lloc on situem el focus d'atenció: en la tecnologia, en l'ampliació de l'educació formal, o en els estudiants i els seus contexts. eLearning i mLearning són processos d'aprenentatge que poden conviure temporalment i es superposen. La principal diferència radica en què el primer implica un aprenentatge virtual i el segon ofereix, com es desprèn del seu propi nom, la possibilitat de la mobilitat gràcies a l'ús de tecnologies portàtils, amb la qual cosa queda amplificada la flexibilitat i llibertat del procés.

Taula 3. Comparativa de terminologies segons Laouris i Eteokleous (2005)

\begin{tabular}{cc} 
eLEARNING & mLEARNING \\
\hline $\begin{array}{c}\text { Ordinador } \\
\text { ample de banda } \\
\text { Multimèdia } \\
\text { Interactiu } \\
\text { Hipervinculat } \\
\text { col·laboratiu }\end{array}$ & Mòbil \\
alt contingut multimèdia & Objectes \\
aprenentatge a distància & Espontani \\
aprenentatge més formal & Connectat \\
situacions simulades & connectat en xarxa \\
aprenentatge virtual & Ileuger contingut multimèdia \\
\hline
\end{tabular}


L'aprenentatge en mobilitat utilitza la tecnologia mòbil no com a fi en sí mateix sinó com a medi per a generar l'aprenentatge asíncron en contextos diversos però que, normalment, són propers a l'usuari. Ens trobem davant la premissa que introduir elements tecnològics no implica innovació, sinó com en fem ús. Mitjançant una metodologia ben definida en la que el paper del professorat és essencial com a guia i on els aprenents gaudeixen d'una gran flexibilitat i familiaritat, experimentaran que són protagonistes del propi aprenentatge. En definitiva, estem d'acord amb Camacho (2011, p. 24) que «el mLearning es el arte de utilizar las tecnologías móviles para potenciar y acentuar la experiencia de aprender».

Quan plantegem l'aprenentatge en mobilitat en l'àrea de Plàstica i Visual (Mascarell, 2013) ens basem, sobretot en l'actualitat, dels nous entorns d'aprenentatge aplicats en les Arts i la Cultura, on les imatges adquireixen el protagonisme vinculat a la nostra contemporaneïtat a través de les pantalles (Huerta 2005; Mascarell, 2017a i 2018). Una bona connectivitat i la ràpida transferència de dades a Internet ens facilitarà l'accés àgil. Amb això, aconseguirem gaudir de recursos digitals molt útils en activitats o experiències educatives en les quals les imatges adquireixen protagonisme, de manera interactiva contribuint al coneixement.

\section{Conclusions}

De la mateixa manera que mLearning es pot entendre com una evolució del eLearning, també l'aprenentatge en mobilitat suposaria el pas anterior del que és l'ubiquitous learning, uLearning o aprenentatge ubic. Es consideraria el punt final de les evolucions dels processos d'aprenentatge en què intervenen les tecnologies. Aquesta premissa implicaria, a més, una adaptació de les metodologies basades en el constructivisme i el connectivisme. Es pot implementar amb la incorporació de qualsevol medi digital actual, possibilitant que tothom puga produir i expandir informació, afavorint la incorporació i assimilació al saber personal, de tal manera que el coneixement es produirà de manera ubiqua, produint (contribuir al coneixement) i adquirint (experimentar aprenentatge).

Les necessitats formatives dels usuaris provoquen canvis continus en els processos d'aprenentatge. Cal, doncs, tenir en compte que l'elearning s'ha d'adaptar a les noves tecnologies i metodologies, amb la qual cosa es produeix una evolució natural cap al mLearning (model que es desenvolupa en l'actualitat) i que serà el primer pas cap a l'uLearning. Amb aquest, segons els experts en la matèria, s'arribaria als nivells desitjats de maduresa i eficiència plena de l'aprenentatge virtual. El futur està en la fase de desenvolupament de l'uLearning, que es recolza en la realitat augmentada. L'Informe Horizon 2018 fa referència a la realitat mixta, la intel-ligència artificial, la robòtica i el redisseny d'espais d'aprenentatge. Pel que fa a I'Informe Horizon 2019, en el seu resum i en referència a l'educació superior, contempla el Mobile Learning com la tecnologia d'aprenentatge que es preveu s'instaure a curt termini, a 1 any vista o menys. És a dir, a hores d'ara, 2020, s'hi estaria produint la incorporació educativa. Paradoxalment ha estat l'actual crisi sanitària mundial la que ha forçat de manera inevitable a una praxi educativa formal mediada per dispositius mòbils. L'ús dels smartphones, entre altres dispositius portables, és una de les alternatives més útils per a les famílies. Els possibilita continuar amb l'activitat educativa de manera telemàtica des de la pròpia llar i sense haver de recórrer a altres dispositius de 
major cost econòmic. Tanmateix els tècnics en educació fiquen sobre la taula les conseqüències que sobre la formació de milers d'alumnes té l'existència de l'encara àmplia bretxa digital, ara més palesa que mai. 


\section{Referències}

Abad, M.; Palacios G. (2008) «Escribir el lugar: collaborative projects in public spaces». International Journal od Education through art, 4 (2), p. 195-206. [data de consulta: 20 novembre 2015].

Boyd, D.M. i Ellison, N.B. (2007) «Social network sites: Definition, history, and scholarship». Journal of Computer-Mediated Communication, 13, p. 210-230. [data de consulta: 7 febrer 2014].

Brazuelo, F.; Gallego, D. (2011) Mobile Learning. Los dispositivos móviles como recurso educativo. Sevilla, Mad (Eduforma).

Cabrera, M. A. (coord.) (2011) Evolución tecnológica y cibermedios. Sevilla, Comunicación Social.

Camacho, M. (2011) «Mobile Learning y el aprendizaje emergente en el ámbito educativo: retos y potencialidades». Infoeventos. [data de consulta: 25 febrer 2012]. https://es.slideshare.net/marcamacho/mobile-learning-y-aprendizaje-emergente

Fumero, R. (2010) «Una sociedad en movilidad: nuevas fronteras. La red en el móvil». Telos, Revista de Pensamiento sobre Comunicación, Tecnologia y Sociedad, 83. [data de consulta: 3 març 2011].

Flores, C.; Roig, R. (2016) «Percepción de estudiantes de Pedagogía sobre el desarrollo de su competencia digital a lo largo de su proceso formativo». Estudios pedagógicos, 42 (3), p. 129-148.

https://rua.ua.es/dspace/bitstream/10045/62548/1/2016_Flores_Roig_EstudPedag. pdf_[data de consulta: 7 desembre 2016].

Fundación Telefónica (2016) Si lo vives, lo compartes. Cómo se comunican los jóvenes en un mundo digital.

file:///C:/Users/USUARIOPC/Downloads/Si_lo_vive_lo_compartes\%20(2).pdf [data de consulta: 15 novembre 2016].

García, M.; Monferrer, J. (2009) «Propuesta de análisis teórico sobre el uso del teléfono móvil en adolescentes». Comunicar, 33, p. 83-92. [data de consulta: 18 gener 2012].

Huerta, R. (2005) Apaga-la! De com Tirant va combatre l'esquizofrènia de les pantalles. València, Institució Alfons el Magnànim.

Huerta, R.; Morant, R. (2010) «Germans de Mario. Xiquets de primària jugant amb les seues consoles DS». Temps d'Educació, 38, p. 227-242. Disponible a: http://www.raco.cat/index.php/TempsEducacio/article/viewFile/211449/281639 [data de consulta: 27 febrer 2011].

Informe Horizon. (2018) NMC Higher Education Edition. Disponible a: https://library.educause.edu/ /media/files/library/2018/4/previewhr2018.pdf [data de consulta: 2 febrer 2018].

Informe Horizon. (2019) Resumen Educación Superior. Disponible a: https://intef.es/Noticias/resumen-informe-horizon-2019/ [data de consulta: 10 febrer 2020].

Koole, M. (2009) «A Model for Framing Mobile Learning». A Ally, Mohamed (Ed.) Mobile Learning Transforming the Delivery of Education and Training, p. 25-50. Canada: Au Press. $\quad$ http://www.aupress.ca/books/120155/ebook/99Z_Mohamed_Ally_2009MobileLearning.pdf [data de consulta: 4 abril 2012].

Laouris, Y.; Eteokleous, N. (2005) «We need an Educationally Relevant Definition of Mobile Learning». In mLearn 2005 - 4th World conference on mLearning Cape Town, South 
Africa.

http://citeseerx.ist.psu.edu/viewdoc/download?doi=10.1.1.106.9650\&rep=rep1\&typ e=pdf_[data de consulta: 28 març 2013].

Levinson, P. (2004) The story of the world's most mobile medium and how it has transformed everything! New York, Palgrave Macmillan.

Mascarell, D. (2013) «"Salvem el Cabanyal". Alumnado de Magisterio produce Cultura Visual a través de sus teléfonos móviles». A Edarte, Grupo de investigacion (ed.) Investigar con jóvenes: ¿Qué sabemos de los jóvenes como productores de Cultura Visual?. Pamplona, Edarte (UPNA/NUP), p. 233-243. http://academicae.unavarra.es/handle/2454/19800_[data de consulta: 22 novembre 2013].

Mascarell, D. i Huerta, R. (2017a). Les TIC en la formació universitària de mestres. El telèfon mòbil en la didàctica de l'Expressió Plàstica a la Facultat de Magisteri de la Universitat de València (tesi doctoral). Universitat de València, València, Espanya.

Mascarell, D. (2017b) «Dispositius mòbils com a nous entorns d'aprenentatge. Contextos emergents en les arts visuals». A Huerta i Alonso-Sanz (eds.), Nous entorns d'aprenentatge per a les arts i la cultura. Valencia, Tirant Humanidades, p. 147-158.

Mascarell, D. (2018) «Las imágenes y su pluralidad en la contemporaneidad digital. Un enfoque pedagógico desde la educación en Artes Visuales». En Huerta, Alonso-Sanz i Ramon, R. (eds.), Investigary Educar en Diseño Valencia, Tirant Humanidades, p. 189201.

Musiał, K.; Kazienko, P. (2013) «Social Networks on the Internet». World Wide Web, 16 (1), p. 31-72. [data de consulta: 16 febrer 2017].

Pérez, J. M.; Pi, M. (2014) «Tecnología y pedagogía en las aulas. El futuro inmediato en España». Aula Planeta. p. 84.

http://www.aulaplaneta.com/descargas/aulaPlaneta_Perspectivas-2014.pdf

Prensky, M. (2011) Enseñar a nativos digitales. Londres, SM.

Ramírez, M. S. (2009) «Recusos tecnológicos para el aprendizaje móvil (MLearning) y su relación con los ambientes de educación a distancia: implementaciones e investigaciones». Revista RIED, 12 (2), p. 57-82. Disponible a: http://www.biblioteca.org.ar/libros/141689.pdf [data de consulta: 8 febrer 2016]. 


\section{El teléfono móvil: Dimensión y recurso educativo. Trabajar con imágenes en el con- texto de las Artes Visuales.}

Resumen: El artículo se enmarca dentro de los resultados de la tesis doctoral Las TIC en la formación universitaria de maestros. El teléfono móvil en la Didáctica de la Expresión Plástica a la Facultad de Magisterio de la Universitat de València (2017a). Ofrece una visión poliédrica del teléfono móvil: Dimensión, evolución, función social e histórica, hasta llegar a cuestionar las oportunidades que aporta este dispositivo en una vertiente de carácter educativo y artístico, a través del Mobile Learning o aprendizaje en movilidad. Nuestro interés radica, desde la perspectiva de las Artes Visuales, en el trabajo mediante las imágenes, ofreciendo propuestas alternativas de trabajo. Se expone la teoría relativa al Mobile Learning, mostrando los beneficios que puede suponer el aprendizaje móvil y ubicuo en nuestros días. Se proclaman las oportunidades pedagógicas que debemos fomentar en las aulas del siglo XXI para ser consecuentes con la realidad social y tecnológica que nos rodea.

Palabras clave: Teléfono móvil, educación, aprendizaje en movilidad, imágenes, artes visuales, magisterio.

\section{Le téléphone portable: dimension et ressource éducative. Travailler avec des images dans le contexte des arts visuels}

Résumé: L'article suivant s'inscrit dans le cadre des résultats de la thèse de doctorat intitulée Les TIC dans la formation universitaire des instituteurs. Le téléphone portable dans la Didactique de l'expression plastique à la Faculté de formation des enseignants de l'Université de Valence (2017a) qui offre une vision polyédrique du téléphone portable : de sa dimension, évolution, fonction sociale et historique, jusqu'au questionnement des opportunités offertes par ce dispositif dans un aspect de caractère éducatif et artistique, à travers l'apprentissage en mobilité. Notre intérêt réside, dans la perspective des arts visuels, dans le travail au moyen des images, en offrant des propositions alternatives de travail. L'auteur de l'article expose la théorie relative au Mobile Learning, en montrant les bénéfices que peut supposer l'apprentissage mobile et omniprésent à notre époque. En outre, il évalue les opportunités pédagogiques qu'il faut encourager dans les classes du $\mathrm{XX|}$ siècle pour être en phase avec la réalité sociale et technologique qui nous entoure.

Mots clés: Téléphone portable, éducation, apprentissage en mobilité, images, arts visuels, corps enseignant.

\section{The mobile phone as an educational resource. Working with images in the Visual Arts context.}

Abstract: This text is part of the doctoral thesis ICT in the university teacher education. The mobile phone in the Teaching of Artistic Expression at the Faculty of Pedagogy at the Universitat de València (2017a). It offers a many-faceted view of the mobile phone - its dimension, evolution, social and historical function - and explores the opportunities that this device brings in an educational and artistic context through Mobile Learning. From the perspective of the Visual Arts, our interest lies in working through images and offering alternative work proposals. The theory related to Mobile Learning is presented, underlining the benefits that mobile and ubiquitous learning can represent today. The teaching opportunities that we must promote in the classrooms of the 21 st century are assessed in terms of their relevance and appropriateness in the social and technological reality that surrounds us.

Keywords: Mobile Phone, Education, Mobile Learning, Images, Visual Arts, Teachers Training. 